\title{
С. А. ЕСЕНИН И ПРОБЛЕМЫ ЭКОЛОГИЧЕСКОГО СОЗНАНИЯ
}

\author{
И. С. Иванова \\ Московский гуманитарный университет
}

\begin{abstract}
Аннотация: В статье рассматривается отношение С. Есенина к урбанизации, внедрению в жизнь достижений науки и техники и к природе. Указывается, что первоначально поэт был противником, а также урбанизации, воспринимал данное явление как категорию ужасного. В отношении С. Есенина к природе заключается особая философия. Из философских и эстетических исканий С. Есенина следует вывод: природа и достижения должны находиться в гармонии, не вредить друг другу и человеку, а помогать им.

Ключевые слова: С. А. Есенин; природа; экология; экологическое сознание
\end{abstract}

\section{S. A. YESENIN AND ENVIRONMENTAL AWARENESS ISSUES}

\author{
I. S. Ivanova \\ Moscow University for the Humanities
}

\begin{abstract}
The paper deals with S. Yesenin's attitude towards urbanization and the implementation of scientific and technical achievements, and towards nature. It is indicated that the poet was initially opposed to urbanization, perceived this phenomenon as a category of the horrible. There is a special philosophy in Yesenin's attitude towards nature. The poet's philosophical and aesthetic pursuit makes it possible to conclude that nature and achievements should be in balance, not harming each other or people, but assisting them.
\end{abstract}

Keywords: S. A. Yesenin; nature; ecology; environmental awareness

В данной статье мы ставим целью рассмотреть отношение С. Есенина к к природе. Эта тема представляется актуальной и потому, что идет Год экологии и потому, что природные катаклизмы последних лет (пожары в лесах, исчезновение целых видов животных, гибель большого количества дельфинов, птиц) - приобрели устрашающие масштабы, а безответственное отношение к природе человека становится губительным для мест его нахождения.

С. Есенин как поэт, воспевающий природу, оказался в центре глобальной проблемы современности, которой можно дать название «Изменение среды обитания человека в период активизации промышленного разви- 
тия в России, в период урбанизации и его последствия». Казалось бы, русский классик застал и отразил самое начало этого процесса: появление паровоза вместо коня, асфальтовые дороги в деревнях, новую технику на полях. Сначала поэт повествует об этом с болью и враждебностью, затем с признанием своей ошибки и выбивающимися из контекста всей его лирики строчками стихотворения «Неуютная жидкая лунность»:

Но и все же хочу я стальною

Видеть бедную, нищую Русь (Есенин,1975: 217).

В статье О. В. Перцова « Живое и железное», посвященной С. Есенину и другим поэтам, коснувшихся экологических проблем, как контекстуальные антонимы употребляются слова «живое» и «железное» (Перцов, Электр. ресурс). Они создают антитезу, характеризующую два полюса творчества поэта: милую сердцу природу и враждебный мир техники, города.

Но если посмотреть в глубину мировидения С. Есенина, увидеть его стихи в контексте писем и статей поэта, то можно заметить, что в стихах о природе и угрожающему ей заключена особая философия, которая лучше отражается через контраст «имеющее душу» и «бездушное». Философы, например, И. Кант, говоря о человеке, давно противопоставляли в нем природное, подчиненное законам земной необходимости, и духовное, трансцендентное начало. Есенин ближе к пантеизму Спинозы. Данный ученый в труде «Этика» писал: «Вся сотворенная природа есть единое существо. Отсюда следует, что человек есть часть природы, связанная с остальными» (Спиноза, 1957: 301).

Спиноза говорил: «Под natura naturata я понимаю все то, что вытекает из необходимости природы бога, иными словами, - каждого из его атрибутов, т.е. все модусы атрибутов бога, поскольку они рассматриваются как вещи, которые существуют в боге и без бога, не могут ни существовать, ни быть представляемы.

...вся природа составляет один индивидуум, части которого, т. е. все тела, изменяются бесконечно многими способами без всякого изменения индивидуума в его целом (там же: 419).

Все живое, по мысли С. Есенина, имеет душу, а душа - частица Бога, и именно здесь, на мой взгляд, поэт близок к пантеизму Б. Спинозы. Но у Есенина все неживое, то есть принадлежащее к неорганической природе, бездушно. За противопоставлением живое - неживое, антитеза душа - бездушность.

Если мы рассмотрим лирику Есенина через призму данного противопоставления, то увидим, что сейчас, на новом витке, когда механизация превратилась частично в роботизацию, а уровни современных технологий таковы, что несколько простых аварий на АТС могут всю землю превратить в Чернобыль, возникает проблема сохранения и воскрешения души 
человека и ее правильного отношения к миру, в частности и к среде своего обитания. Говоря о природе, С. Есенин в труде «Ключи Марии» (1918) ставит вопрос о душе. У него все живое одухотворено, живет чувствами и большей частью добрыми, которым надо учиться цивилизованным, но еще не культурным людям. Собака любит своих щенков и тоскует по ним, а некоторые люди хуже собаки: не только щенков топят, но своих детей бросают, не помогают материально и морально и даже не мучаются совестью. Олицетворение у С. Есенина - не простой художественный прием, а отражение его философии, по которой материя природы обладает разумом и чувством.

Понимание С. Есениным природы близко к философии Ф. И. Тютчева, воплощенной в стихотворении «Не то, что мните Вы, природа», в котором поэт и дипломат утверждает, что в природе «есть душа, в ней есть свобода, в ней есть любовь, в ней есть язык...» (Тютчев, 1995: 117). По мнению Ф. И.Тютчева, отношение к природе как к бездушному существу бывает у людей бесчувственных, которых не взволнует и голос мамы. Действительно, чем душевнее человек, тем чаще его трогает красота естественного мира. Есенин видит в красоте природы и ее изображению в искусстве религиозную философию.

Правильному отношению к природе, по мысли С. Есенина, надо учиться у наших предков, кстати, не только у славян-язычников. Развивая вышеприведенные мысли С. Есенина, высказанные в труде «Ключи Марии», можно сказать, что правильному отношению к природе надо учиться у наших предков, в том числе и у славян-язычников. Из текста данной статьи С. Есенина эти люди относились природе и ее силам с огромным уважением, так как понимали, что правильное отношение к окружающему миру позволит человеку уцелеть и, познав тайны природы, жить в гармонии с ней. Поэт пишет: «Обоготворение сил природы, выписанное лицо ветра именем Стрибога или Борея в мифологиях земного шара есть не что иное, как творческая ориентация наших предков в царстве космических тайн» (Есенин, 1918: 199). Сегодня повсюду, в Москве и за ее пределами, вырубаются деревья, целые леса. При этом их часто не заменяют другими. Вырубленные участки покидают птицы, размножаются насекомые и губят урожай. Отчасти такое отношение к деревьям проистекает из утверждения Е. Базарова, что природа является не храмом, а мастерской, в которой человек должен радостно трудиться. Поэзия и философия С. Есенина заставляет нас вернуться к восприятию природы как к храму, к культу, объекту культуры, который и самоценен для души человека. Именно такое отношение ней может остановить людей, которые ради утверждения ценностей готовы губить природу, в частности деревья, не думая о последствиях. 
В посвященной А. Мариенгофу работе «Ключи Марии» поэт обращается к мощному мифологическому сознанию землян и указывает, как хорошо понимали люди раньше, что они зависят от древа, а потому поклонялись ему. А. Марченко в книге «Поэтический мир С. Есенина» подробно рассматривает древесную образную систему стихов С. Есенина, находит в ней следы языческого поклонения древу и цитирует строки С. Есенина из «Ключей Марии» «Вытирая лицо свое о холст с изображением древа, наш народ немо говорит о том, что он не забыл тайну древних отцов вытираться листвою, что он помнит себя семенем надмирного древа...» (Марченко, 1989: 60).

Продолжая логически мысль С. Есенина, можно сказать, что древо у поэта - образ многозначный: это и символ человека, имеющего семью, которая тогда не распадается, когда все ее члены правильно относятся друг к другу, это и символ вселенской семьи, единства всего живого, потому что поэт упоминает надмирное древо. Подтвержает эти мысли и сам текст С. Есенина в статье «Ключи Марии». Поэт пишет, что в орнаменте славян часто присутствует «то символическое древо, которое означает «семью». Совсем не важно, что в Иудее это древо носило имя Маврикийского дуба и потому вместе с христианством перешло, как название, бесплатным приложением к нам. Скандинавская Иггдразиль - поклонение ясеню, то древо, под которым сидел Гаутама, и этот Маврикийский дуб были символами «семьи» как в узком, так и широком смысле у всех народов (Есенин, 1918: 188-189).

Если взять эту идею в переносном плане, можно понять, что связи ветвей и ствола и листьев - это и связи в социальной семье, что древо -человек в его социальных связях. Через поэтический образ древа нам говорят уже об экологии сознания, которая, в частности, заключается в том, чтобы правильно выбрать шкалу истинных ценностей и ту картину мира, которую надо оберегать и защищать. Убежденность необходимости поклонения древу Есенин переносит и в лирику. «Молюсь осинам», - говорит его герой в стихотворении «Возвращение на Родину» (Есенин, 1975: 138). Конечно, в контексте всего стихотворения это звучит с иронией, так речь идет о том, что новая власть насильно лишает крестьян веры в христианского Бога и икон, но в каждой шутке есть доля правды: языческая вера жила в народе и при христианстве.

Замечательная исследовательница творчества поэта А. Марченко пишет, что дерево (древо) - центральный образ поэзии С. Есенина, в котором сосредоточены «философия, мироощущение» поэта (Марченко, 1989: 56).

Российский классик использует образ дерева для деталей своего автопортрета: «Старый клен головой на меня на меня похож» (Есенин, 1975: 111); «скоро белое дерево сронит головы моей желтый лист» (там же: 114). 
Он изображает людей - листьями сада, женщину - березкой. А. Марченко пишет: «Тайным родством связал Есенин златоглавого юношу (...) с кленом. Под стать этому песенному клену и его березка. Она тоже - живая. Есенин и ее одел в «холщовый сарафан», запутал в ее золотистые косы лунный гребень» и даже заставил ее, босоногую, ревновать барышнечеремухе» (Марченко, 1989: 85). Фактически А. Марченко описывает прием олицетворения, корни, безусловно, таятся в народном творчестве, где береза - символ красоты, стройности, молодости.

Позднее белоствольная царица русского пейзажа у Есенина превратится в символ обобщающей силы, воплощая любовь поэта к Родине». Изображение древа как человека - это не просто продолжения приема параллелизма, знакомого нам из устного народного творчества, но, напротив, прием соединения, взаимосвязи, продолжения одного живого существа в другом и даже экзистенциального прорыва.

По мнению А. Марченко, в есенинском творчестве проповедуется идея «узловой завязи природы ... с сущностью человека» (там же: 59). Это означает, что человек - часть природы, часть целого, а, если исчезнет целое - природа, то не будет и части - человека. Вредя природе, человек вредит себе, убивает свою душу, способность чувствовать и сочувствовать. Особое внимание Есенин уделяет проблеме уважения к людям, работающим с природой, создающим материальные ценности, например, хлеб. Поэт чувствует, что наступление города на деревню несет презрение и даже ненависть к людям этого труда и пишет в стихотворении «Мир таинственный, мир мой древний»: «Город, город, ты в схватке жестокой окрестил нас как падаль и мразь» (Есенин, 1975: 125).

Слово «деревенщина» часто ассоциируется с отсутствием культуры. Но, рассказывая об убранстве избы крестьянина, С. Есенин подчеркивает одухотворенность, культурность ее деталей, направленных на доброе отношение к людям и миру. Изображения созданий живой природы издавна окружали человека в быту. Есенин рассматривает убранство крестьянской избы и находит символы духовных движений в образах природы.

«Голубь на князьке крыльца есть знак осенения кротостью. Это слово пахаря входящему. Кротость веет над домом моим, кто б ты ни был, войди, я рад тебе» (Есенин, 1918: 192). Рассказывая о философском значении убранства дома крестьянина, С. Есенин предпочитает рассматривать его части и вещи с языческой точки зрения и народного параллелизма, при котором человеческое соответствует природному. Он говорит: «Красный угол, например, в избе есть уподобление заре, потолок - небесному своду» (там же: 194).

С. Есенин подчеркивает, что недостаточное уважение к людям, которые через общение с природой получают хлеб свой, связано с невеже- 
ством, незнанием мифологического сознания предков и неумением читать символические значения по представленным знакам.

«Если б хоть кто-нибудь у нас понял в России это таинство, которое совершает наш бессловесный мужик, тот с глубокой болью почувствовал бы мерзкую клевету на эту мужичью правду всех наших кустарей и их приспешников. Он бы выгнал их, как торгующих из храма, как хулителей на святого духа...» (там же: 192). Не замену живого на механическое видит С. Есенин в процессе, но убиение души.

Достижения науки человек ухитрился использовать для уничтожения человечества: изобреталось все более совершенное оружие, людей в Первую мировую войну уже травили газами. Антивоенные ноты в стихах и поэме С. Есенина «Анна Снегина» (1925) - это тоже протест против неправильного использования промышленности и науки, достижения которых попали в руки нечистоплотных политиков.

Отказ от участия в военных действиях звучит в стихотворении «Кобыльи корабли». Обращаясь зверям, поэт говорит:

Никуда не пойду с людьми,

Лучше вместе издохнуть с вами,

Чем с любимой поднять земли

В сумасшедшего ближнего камень (Есенин, 1975: 116).

В стихах Есенина мы видим пример правильного отношения человека к любимой природе. В произведении «Кобыльи корабли» он пишет: «Не обижу ни козы, ни зайца» (там же: 116).

В стихотворении «Мы теперь уходим понемногу» поэт говорит, что был счастлив, так не испытывал муки совести за плохое отношение к животным, «зверье как братьев наших меньших никогда не бил по голове» (там же: 202).

Для Есенина природа - это и дом его стихов, и источник вдохновения. Образы С. Есенина часто зооморфны, но в их зооморфичности есть особая этика, как пишет В. О. Перцов: «В той веренице образов животного мира, который обступает читателя с первых стихотворений раннего Есенина, не может не поразить отношение поэта к “зверью” как к “братьям нашим меньшим”. Смешанное чувство жалости, родственности, ответственности перед ними. “Думает грустную думу о белоногом телке”: “Свяжут ей петлю на шее и поведут на убой” (“Корова”). “На раздробленной ноге приковыляла, у норы свернулася в кольцо” (“Лисица”), “Рыжий месяц жеребенком запрягался в наши сани”, “Осень - рыжая кобыла - чешет гриву”; “Ягненочек кудрявый - месяц гуляет в голубой траве” (Перцов, Электр. ресурс). Надо добавить, что анималистические стихи С. Есенина, особенно «Песнь о собаке», вызывают не только жалость к животным, но философские раздумья о том, что все живое имеет душу. 
Наступление города на деревню вызвало у Есенина боль и тревогу, так как погибал и источник вдохновения поэта. В поэме «Сорокауст» бежит жеребенок, стремясь обогнать железный поезд и проигрывая; в стихотворении «Мир таинственный, мир мой древний» «сдавили за горло деревню руки каменные шоссе», «стынет поле в тоске волоокой, телеграфными столбами давясь» (Есенин, 1975: 125).

В произведении «Сорокоуст» «головой размозжась о плетень, разлилась кровью ягод рябина» (там же: 120). Название стихотворения символично. Сорокоуст для людей верующих - это молитвы по ушедшему в иной мир человеку в продолжении сорока дней после смерти. Ушедшим в данным случае является мир природы, деревни. Действительно, в большинстве стихотворений С. Есенина, созданных в период наступления города на деревню, живое либо гибнет, либо не принимает перемен, что особенно ярко видно в образе поля, которое давится телеграфными столбами.

У С. Есенина в «Сорокоусте» есть намек и на то, что напрямую связана с концом света. Слова «трубит, трубит погибельный рог» (Есенин, 1975:118) являются аллюзией: перед помнящими Библию возникают трубы последней битвы Бога с Сатаной и картины Страшного суда. На мой взгляд, этот разрыв естественных связей сопровождается формированием связей искусственных, способствующих умерщвлению личности. Поэт предвидел, как урбанизация и внедрение технических новшеств повлияют на изменение души человека.

Сегодня массовое использование автомобилей сделало воздух загазованным, применение вредных аэрозольных веществ создало вредные озоновые дыры, полным ходом пошло разрушение не только биосферы, но и атмосферы. Действительно, неживое активно уничтожает живое, убивает и души многих людей, которые за дорогой айфон или автомобиль готовы отдать многое.

Роль художественной литературы в формировании правильного отношения к природе, НТР и экологическим проблемам очень велика и вместе с бережным отношением к природе мы должны передавать будущим поколениям любовь и уважение к стихам С. Есенина и творчеству других поэтов, писателей, художников, философов касавшихся этих проблем.

\section{СПИСОК ЛИТЕРАТУРЫ}

Есенин, С. А. (1975) Стихотворения и поэмы. М. : Худ. лит. 304 с.

Есенин С. А. (1997) Ключи Марии // Есенин С. А. Полное собрание сочинений : в 7 т. М. : Наука ; Голос.

Марченко, А. М. (1989) Поэтический мир Есенина. М. : Советский писатель. 304 с.

Перцов, О. В. Живое и железное [Электронный ресурс] // S-A-Esenin. 
ru: Сергей Александрович Есенин. URL: http://s-a-esenin.ru/books/item/ f00/s00/z0000013/st010.shtml (дата обращения: 02.05.2017).

Спиноза Б. (1957) Избранные произведения: в 2-х томах. Т. 1. М.: Госполитиздат. 630 с.

Тютчев, Ф. И. (1995) «О, вещая душа моя!».. : Стихотворение. Переводы. Размышления о поэте. М. : Школа-пресс. 496 с.

Дата поступления: 15.09.2017 г.

Иванова Ирина Сергеевна - кандидат философских наук, доцент, доцент кафедры философии, культурологии и политологии Московского гуманитарного университета. Адрес: 111395, Россия, г. Москва, ул. Юности, д. 5. Тел.: +7 (499) 374-61-81. Эл. адрес: Lesnaya10@yandex.ru

Ivanova Irina Sergeyevna, Candidate of Philosophy, Associate Professor, Associate Professor, Department of Philosophy, Culturology and Politology, Moscow University for the Humanities. Postal address: 5, Yunosti St., Moscow, Russian Federation 111395. Tel.: +7 (499) 374-61-81. E-mail: Lesnaya10@ yandex.ru

\section{Для циитирования:}

Иванова И. С. С. А. Есенин и проблемы экологического сознания [Электронный ресурс]// Научные труды Московского гуманитарного университета. 2017. № 5. URL: http://journals.mosgu.ru/trudy/article/view/568 DOI: 10.17805/trudy.2017.5.7 (дата обращения: дд.мм.гг.) 